\title{
Public Private Partnership Dalam Penyediaan Infrastruktur Pelayanan Publik: Pengalaman Indonesia dan India
}

\author{
Muhammad Tang Abdullah \\ Program Studi Ilmu Administrasi Publik Fakultas Ilmu Sosial dan Ilmu Politik \\ Universitas Hasanuddin, Makassar, Indonesia 90245 \\ E-mail: muhtangabdullah@yahoo.co.id
}

Received: 28 April 2020; Revised: 21 Oktober 2020; Accepted: 27 Oktober 2020

\begin{abstract}
This study is based on the fact that there are several weaknesses that the government has in the provision of public service infrastructure, both in Indonesia and India. Some of these weaknesses include limited capacity of apparatus resources, budget shortages, management and technology weaknesses in the provision of public service infrastructure. This article aims to see how a public private partnership is conceptually and how the experiences of the Indonesian and Indian states in putting this concept into practice. This study uses qualitative research methods with library research techniques. Literature study is applied with data analysis techniques in several stages. Through this literature study method, it was found that public private partnership is strongly associated with the concept of new public management and governance. There are many forms of public private partnership such as BOT (Build Operate and Transfer), BT (Build and Tranfer), BTO (Build, Transfer, and Operate), BLT (Build, Lease, and Transfer), BOO (Build, Own, and Operate), ROO (Rehabilitate, Own, and Operate), ROT (Rehabilitate, Own, and Transfer), DOT (Develop, Operate, and Transfer), and CAO (Contract, Add, and Operate). But the overall form is essentially aimed at providing infrastructure and public services can be more efficient, effective and economical. In practice, both in Indonesia and India, has had a noticeable effect such as the opening of new jobs for residents because this public private partnership has long been applied in various development sectors, especially in the service of basic community needs, such as education, health, transportation, public housing, social services, and clean water supply.
\end{abstract}

Keywords: Public Private Partnership; Governance; Public Service

\begin{abstract}
Abstrak
Kajian ini didasarkan pada fakta adanya beberapa kelemahan yang dimiliki oleh pemerintah dalam penyediaan infrastruktur pelayanan publik, baik di Indonesia maupun India. Beberapa kelemahan tersebut meliputi keterbatasan kapasitas sumberdaya aparatur, kekuragan anggaran, kelemahan manajemen dan teknologi dalam pengadaan infrastruktur pelayanan publik. Artikel ini bertujuan untuk melihat bagaimana public private partnership secara konseptual dan bagaimana pengalaman negara Indonesia dan India dalam mempraktekkan konsep tersebut tersebut. Kajian ini menggunakan metode penelitian kualitatif dengan teknik studi kepustakaan. Studi kepustakaan diterapkan dengan teknis analisis data dalam beberapa tahap. Melalui metode studi kepustakaan ini ditemukan bahwa public private partnership sangat terkait dengan konsep new public management dan governance. Terdapat banyak bentuk public private partnership seperti BOT (Build Operate and Transfer), BT (Build and Tranfer), BTO (Build, Transfer, and Operate), BLT (Build, Lease, and Transfer), BOO (Build, Own, and Operate), ROO (Rehabilitate, Own, and Operate), ROT (Rehabilitate, Own, and Transfer), DOT (Develop, Operate, and Transfer), dan CAO (Contract, Add, and Operate). Namun keseluruhan bentuk tersebut pada hakekatnya bertujuan agar penyediaan infrastruktur dan pelayanan publik bias lebih efisien, efektif dan ekonomis. Dalam prakteknya baik di Indonesia maupun India telah memberi efek yang nyata seperti terbukanya lapangan kerja baru bagi warga karena public private partnership ini sudah sejak lama diterapkan dalam berbagai sektor pembangunan, terutama pada pelayanan kebutuhan dasar masyarakat, seperti pelayanan pendidikan, kesehatan, transportasi, perumahaan rakyat, soaial, dan penyediaan air bersih.
\end{abstract}

Kata Kunci : Public Private Partnership; Governance; Pelayanan Publik Link DOI : http://dx.doi.org/10.31314/pjia.9.2.102-114.2020 


\section{PENDAHULUAN}

Menelaah kondisi pelayanan publik di Indonesi sekarang ini, maka akan ditemukan banyak variasi penilaian dari berbagai pihak. Penilaian terhadap kondisi riil pelayanan publik oleh sebagian pihak menyimpulkan bahwa wajahnya sudah tampak "buram". Wajah "buram" pelayanan publik banyak ditemui dalam berbagai laporan hasil penelitian dan berita keluhan publik di media massa. Bahkan dapat dilihat langsung fakta carut marutnya manajemen pelayanan publik, termasuk infrastruktur pelayanan itu sendiri yang masih jauh dari situasi yang memuaskan. Wajar kemudian jika Suryadi (2010), menyatakan bahwa pelayanan publik yang disediakan oleh birokrasi pemerintah di semua jenis dan level pemerintahan berada dalam kondisi "patologis".

Dalam pengadaan barang-barang publik seperti infrastruktur jalan tol, jaringan air minum, listrik, pelabuhan, dan bandara, serta bangunan perkantoran untuk memfasilitas aktivitas dan mobilitas ekonomi masyarakat juga mengalami persoalan, baik dalam hal sumber daya maupun manajemen pengadaannya. Oleh karena itu menurut Utama (2010), pemerintah seharusnya mengembangkan model kerjasama dengan pihak swasta sebagaimana yang telah lama dilakukan oleh negara-negara Eropa dalam berbagai bidang pembangunan.

Darmin Nasution, Menteri Negara Koordinator Bidang Perekonomian tahun 2018 yang lalu merilis tentang adanya 222 Proyek Strategis Nasional (PSN) yang diimplementasikan mulai tahun ini. PSN yang dimaksud terdiri atas 69 proyek jalan, 51 bendungan, 29 kawasan ekonomi khusus atau kawasan industri atau kawasan pariwisata, 11 proyek energi, 10 pelabuhan, dan delapan proyek air bersih dan sanitasi. Estimasi nilai investasinya lebih dari Rp. 4.100 triliun. Dalam pengarahannya, Presiden RI mensyaratkan agar PSN tersebut dilakukan dalam bentuk partnership yakni pelibatan BUMN dan BUMD serta pihak swasta dalam berbagai aspek pengerjaannya misalnya investasi teknologi, anggaran, dan lahan proyek (bareksa.com, 2018)

Oleh karena itu menurut Abdullah (2016) bahwa berbagai kelemahan dalam organisasi pemerintahan tersebut di atas, bisa dirinci dengan indikasi antara lain: (1) makin berkurangnya anggaran; kelemahan manajemen; dan (3) aparatur yang tidak profesional. Seiring pergeseran paradigma pemerintahan di awal tahun 1990an yakni government ke governance sebagai wujud manifestasi dari pendekatan new public management, sudah disadari bahwa dalam tubuh pemerintah terdapat berbagai kelemahan dalam melaksanakan fungsi dan perannya sebagai public services and goods delivery. Atas d..asar inilah, sehingga mendorong lahirnya konsep kemitraan (partnership) dengan pihak lain (swasta dan masyarakat). Konsep ini selanjutnya dikenal oleh kalangan akademisi sebagai model public private partnership.

Fenomena dan persoalan terkait ketiga kelemahan di atas, rupanya telah menjadi fenomena umum yang melanda sebagian besar negara di dunia terutama pada negara-negara sedang berkembang seperti Indonesia dan India. Misalnya kasus di Indonesia, model public private partnership ini sudah berlangsung sejak tahun 1974 ketika proyek pembangunan jalan tol dimulai. Meskipun ketika itu fokus kerjasama lebih banyak pada bidang infrastrutktur fisik. Regulasi tentang model kerjasama pemerintah dan swasta ini pertama kali diatur dalam Peraturan Pemerintah Nomor 1 Tahun 2008 tentang Investasi Pemerintah. Meskipun sebelumnya sudah terbit Peraturan Presiden Nomor 67 Tahun 2005 tentang Copyright @ 2020, Publik (Jurnal Ilmu Administrasi), ISSN: 2301-573X (Print), ISSN: 2581-2084 (Online) 
Kerjasama Pemerintah dan Badan Usaha dalam Penyediaan Infrastruktur. Dalam perpres ini, unit pemerintah atau badan yang berwewenang secara aktif memfasilitasi kerjasama pemerintah dan swasta adalah Badan Perencanaan Pembangunan Nasional (BAPPENAS), dalam hal ini dibawah kendali Direktorat Pengembangan Kerjasama Pemerintah dan Swasta.

Menurut Utama (2010) bahwa Perpres Nomor 67 Tahun 2005 tersebut di atas kemudian direvisi menjadi Perpres Nomor 13 Tahun 2010. Salah satu aspek yang penting dalam revisi perpres ini adalah apresiasi terhadap ide atau inovasi dari pihak swasta dalam proposal yang diajukan terkait dengan pembangunan infrastruktur dan penyediaan pelayanan lainnya.

Pada dasarnya secara konseptual model public private partnership memiliki beberapa keuntungan di dalam prakteknya. Beberapa keuntungan yang dimaksud seperti dikutip dari European Commision (2003) adalah (1) percepatan dari penyediaan modal untuk pembangunan infrastruktur; (2) adanya pengalihan tanggung jawab desain dan konstruksi kepada pihak swasta dan dikombinasikan dengan pembiayaan oleh pemerintah; (3) adanya pengurangan biaya yang tidak perlu selama masa penggunaan proyek yang dilakukan oleh pemerintah swasta; (4) adanya alokasi resiko kepada pihak yang paling berkompeten untuk menanganinya sehingga pihak swasta akan memperbaiki kualitas manajemennya dan menampilkan berdasarkan pengalaman internasional; (5) pihak swasta diharapkan akan lebih mampu untuk menghasilkan pendapatan tambahan pada masa operasional sehingga subsidi pemerintah dapat dikurangi; (6) pemerintah akan berperan sebagai regulator dan akan memfokuskan perannya pada rencana program pelayanan dan monitoring akibat dari dilimpahkannya tanggung jawab public service kepada swasta.

\section{METODE PENELITIAN}

Fokus kajian adalah penggambaran terhadap model public private partnership secara konseptual dan penerapan konsep tersebut di Indonesia dan India. Agar fokus dapat dipahami secara komprehensif dan mendalam maka digunakan metode pendekatan kualitatif dengan teknik studi kepustakaan (library research).

Teknik studi kepustakaan menurut Zed (2004) adalah kegiatan yang mengharuskan peneliti memperoleh data yang bersumber dari berbagai literatur, tidak hanya buku-buku tetapi juga dapat berasal dari sumber bacaan lain yang dapat menunjang penelitian, seperti laporan penelitian, artikel jurnal, dan dokumen kebijakan (peraturan perundang-undangan) dan program pemerintah. Tentu semua pustaka yang dimaksud di sini hanya berkaitan dengan penerapan model public private partnership dalam berbagai aspek bidang pelayanan dan penyediaan barang publik, baik di Indonesia maupun India. Adapun analisis data kualitatif ini dilakukan dalam beberapa tahap, yakni (1) penyusunan data; (2) klasifikasi data; (3) pengolahan data; dan (4) penafsiran atau penyimpulan.

\section{HASIL DAN PEMBAHASAN \\ Governance dan Public Private Partnership}

Jika mengacu pada teori barangbarang publik (public goods theory), maka pada dasarnya fungsi pelayanan publik merupakan tanggungjawab pemerintah dalam menyediakannya, sedangkan untuk barang privat (private atau economic goods), maka sektor swastalah yang 


\section{Available Online at http://journal.umgo.ac.id/index.php/Publik \\ Publik (Jurnal Ilmu Administrasi) Vol 9 (2), Desember 2020}

menyediakan. Namun pada kenyataannya terdapat beberapa barang campuran, yaitu barang semi publik (quasi public goods) dan semi privat (quasi private goods). Pelayanan publik meliputi penyediaan barang publik murni, semi publik, dan semi privat. Untuk kategori barang campuran ini, baik sektor publik maupun swasta dapat sama-sama menyediakan. Oleh karena itulah kemudian untuk meningkatkan efisiensi dan efektivitas pelayanan publik, pemerintah daerah dapat melakukan program kemitraan dengan sektor swasta (public private partnership) atau bisa juga bekerjasama dengan sektor ketiga yaitu dengan organisasi nonprofit dan LSM (Mardiasmo, 2002).

Salah satu doktrin dalam paradigma new public management yakni menanamkan nilai-nilai persaingan (competitiveness values) untuk itulah organisasi sektor publik perlu mengadopsi prinsip-prinsip mekanisme pasar agar tercipta persaingan di lingkungan internal organisasi (Osborne, 1992).

Tujuan menciptakan persaingan di sektor publik tersebut adalah untuk menghemat biaya (efisiensi) dan meningkatkan kualitas. Satu di antara banyak bentuk pengadopsian mekanisme pasar itu adalah dilakukan mekanisme kontrak, tender kompetitif dalam rangka penghematan biaya dan peningkatan kualitas serta privatisasi. Dalam konteks ini, organisasi pemerintah bisa juga melakukan kontrak kerjsama dengan pihak swasta, masyarakat sipil, dan kelompok relawan (volunteer).

Beberapa tugas pelayanan publik tertentu yang menjadi tanggung jawab pemerintah sebenarnya bisa dikontrakkan ke pihak swasta atau pihak ketiga untuk menanganinya, seperti pemungutan sampah, penarikan pajak, perawatan dan pemeliharaan aset pemerintah, dan sebagainya. Pertimbangan yang perlu dilakukan adalah bahwa apabila dengan dikontrakkan pemerintah bisa menghemat pengeluaran dan memperoleh hasil yang lebih berkualitas, maka pengontrakan kerja adalah lebih baik. Selain itu, manfaat lainnya adalah mendorong sektor swasta dan sektor ketiga untuk berkembang (Mahmudi, 2005). Terkait dengan bentuk hubungan kemitraan tersebut, oleh Savas (1994) mengemukakan adanya sepuluh model public private partnership dalam praktek pelayanan publik, yaitu:

a) Government Services, dalam model ini pemerintah sepenuhnya menetapkan kebijakan, pendanaan serta penyedia pelayanan. Contoh: pelayanan pertahanan;

b) Government Vending, dalam model ini pemerintah sebagai penyedia pelayanan, sedangkan kebijakan dan konsumen sepenuhnya berasal dari konsumen, yaitu masyarakat atau organisasi masyarakat. Contoh layanan seperti ini adalah kegiatan masyarakat (seperti festival band) yang memerlukan pengamanan dari pemerintah (dalam hal ini: polisi);

c) Intergovernment agreement yaitu kerjasama antara pemerintah daerah satu dengan pemerintah daerah lainnya. Contoh: pengelolaan sampah bersama antara beberapa pemda;

d) Contrac yaitu pemerintah menetapkan kebijakan dan biaya, pelaksana pihak lain, sedangkan masyarakat menjadi konsumen. Contoh pelayanan ini, seperti pembangunan jalan yang dikontrakkan ke kontraktor swasta;

e) Franchise yaitu pihak pemerintah menetapkan kebijakan publik, swasta sebagai penyedia (produsen) pelayanan, sedangkan masyarakat berperan sebagai konsumen yang harus membayar pelayanan publik yang di konsumsinya. Contoh: pelayanan taksi;

Copyright (c) 2020, Publik (Jurnal Ilmu Administrasi), ISSN: 2301-573X (Print), ISSN: 2581-2084 (Online) 
f) Grant yaitu pihak pemerintah dan masyarakat yang menetapkan kebijakan dan sekaligus yang membiayai pelayanan ini. Sedangkan swasta yang menjadi penyedia pelayanan. Biaya yang dikeluarkan pemerintah dianggap sebagai subsidi;

g) Voucher, yaitu dalam model ini kebijakan atau aturan main ditetapkan oleh masyarakat sebagai konsumen, sedangkan pemerintah memberikan subsidi dan swasta yang menyediakan pelayanan;

h) Market yaitu bahwa dalam model ini, konsumen menetapkan aturan main dan membiayai semua layanan yang disediakan, sedangkan swasta memberikan layanan. Pemerintah sama sekali tidak berperan;

i) Voluntary yaitu bahwa dalam model ini pemerintah dan swasta tidak berperan apapun, semua penyediaan pelayanan disenggarakan oleh lembagalembaga masyarakat (seperti LSM atau organisasi masyarakat);

j) Self Services yaitu bahwa dalam model ini baik pemerintah, swasta, atau lembaga masyarakat tidak berperan apaapa, semua penyediaan pelayanan dan pembiayaan dilakukan langsung oleh masyarakat.

Bentuk kerjasama pemerintah dengan swasta bisa berupa kontrak kerja, tender penyediaan barang atau jasa, atau bisa juga berupa business process outsourcing (OECD, 1997). Menurut OECD bahwa model kemitraan yang dapat diadopsi oleh negara-negra berkembang termasuk Indonesia dan India, antara lain: (1) kontrak pelayanan (service contract); (2) kontrak pengelolaan (management contract); (3) kontrak sewa (lease contract); (4) bangun-kelola-alih milik (Build, Operate and Transfer); (5) bangunkelola-miliki-alih milik (Build, Operate,
Own, and Transfer); dan (6) model konsesi (concession).

\section{Penerapan Public Private Partnership}

Strategi public private partnership merupakan model kemitraan yang didasarkan pada kerangka penyedia terbaik (best sourcing). Dengan kerangka best sourcing tersebut, diasumsikan bahwa pemerintah dapat mendorong sektor swasta untuk terlibat dalam memberikan pelayanan publik tertentu yang mana hal itu akan lebih meningkatkan efisiensi dan efek-tivitas pelayanan (value for money) dan memberikan win-win solution baik bagi pemerintah maupun pihak swasta.

Meskipun demikian, model ini tidak selalu tepat diterapkan pada semua kondisi. Oleh karena dalam suatu dokumen The Stationery Office (2000), disebutkan sejumlah alasan yang mestinya terperhatikan jika ingin mempraktekkan model public private partnership ini, yang meliputi:

a) Pemerintah menghadapi keterbatasan dana dan sumber daya manusia yang kompeten dalam menyediakan pelayanan tersebut;

b) Pihak swasta dapat memberikan pelayanan dengan kualitas yang lebih baik dibandingkan bila diberikan oleh pemerintah;

c) Pihak swasta dapat menjamin bahwa pelayanan dapat diberikan lebih cepat dibandingkan bila disediakan oleh pemerintah;

d) Ada dukungan dari pengguna jasa untuk melibatkan pihak swasta sebagai penyedia pelayanan;

e) Ada peluang kompetisi di antara para calon mitra swasta;

f) Tidak ada ketentuan perundangundangan yang melarang pelibatan pihak swasta dalam penyediaan jasa pelayanan; 
g) Luaran dari pelayanan dapat dengan mudah diukur dan ditetapkan tarifnya dengan rasional;

h) Biaya pelayanan dapat diperoleh kembali melalui penetapan tarif penggunaan jasa layanan;

i) Ada peluang inovasi dalam penyediaan pelayanan;

j) Ada rekam jejak (track record) atau pengalaman kemitraan antara pemerintah dan swasta yang sudah dilakukan sebelumnya;

k) Ada peluang untuk mendorong pertumbuhan ekonomi melalui kemitraan tersebut.

Jika salah satu dari alasan-alasan tersebut tidak terpenuhi, maka sebaiknya tidak diterapkan, karena model tersebut rentan dengan risiko finansial dan resiko politis, yang dapat membebani masyarakat pengguna jasa layanan di kemudian hari.

Kemudian menurut Kouwenhoven (1993), bahwa sebelum menerapkan public private partnership, terdapat sejumlah prakondisi yang perlu dipersiapkan agar public private partnership dapat mencapai hasil yang dikehendaki, yang dikenal sebagai "process conditions". Sejumlah prakondisi yang dimaksuk meliputi: (1) mutual trust; (2) unambiguity and recording of objectives and strategy; (3) unambiguity and recording of the division of cost, risks and returns; (4) unambiguity and recording of the division of responsibilities and authorities; (5) phasing of the project; (6) conflict regulation laid down beforehand; (7) legality; (8) protection of the third parties' interests and rights; (9) adequate support and control facilities; (10) business and market oriented thinking and acting; (11) internal coordination; dan (12) adequate project organization.
Praktek Public Private Partnership: Konteks di Indonesia dan India

Pada awalnya praktek model public private partnership ini lebih banyak diterapkan dalam program-program yang terkait dengan pelayanan atau pengadaan infrastruktur yang bersifat fisik, seperti yang banyak dipraktekkan di Indonesia. Kemudian dalam prakteknya berkembang ke program-program yang terkait dengan pelayanan publik sektor sosial, seperti pendidikan, kesehatan, air bersih dan sanitasi, pemberdayaan ibu dan anak, sebagaimana dipraktekkan di India. Untuk mengetahui lebih jauh bagaimana praktek public private partnership tersebut, pada bagian berikut disajikan gambaran singkat tentang bagaimana praktek model dikedua negara tersebut berlangsung.

\section{- Praktek Public Private Partnership di Indonesia}

Dalam konteks prakteknya di Indonesia, sejak tahun 1987, pemerintah telah mengeluarkan Keputusan Presiden Nomor 15 Tahun 1987 tentang kemitraan antara sektor pemerintah-swasta dalam kegiatan investasi dan manajemen penyediaan prasarana ekonomi seperti pembangunan sistem jaringan jalan raya, jaringan air bersih perpipaan, pelabuhan laut dan udara, tenaga listrik, telekomunikasi, dan prasarana lainnya. Alhasil dalam pelaksanaan kebijakan kepres tersebut telah berhasil memobilisasi sumberdaya dari berbagai pihak swasta, baik dari dalam negeri maupun dari pihak swasta luar negeri untuk kepentingan investasi di bidang pelayanan publik.

Selanjutnya dalam Tarigan (2003), disebutkan bahwa pada tahun 1998, untuk merespon keterbatasan sektor publik dalam penyediaan anggaran untuk pelayanan publik dan pelibatan usaha swasta dalam kegiatan investasi prasarana publik yang juga berkaitan dengan terjadinya krisis Copyright @ 2020, Publik (Jurnal Ilmu Administrasi), ISSN: 2301-573X (Print), ISSN: 2581-2084 (Online) 
ekonomi yang berkepanjangan. Pemerintah mengeluarkan Keputusan Presiden Nomor 7 Tahun 1998 untuk menjabarkan cara pengaturan dalam rangka kerjasama kemitraan sektor publik (pemerintah) dan swasta.

Berdasarkan Peraturan Presiden Nomor 67 Tahun 2005 yang kemudian direvisi menjadi Peraturan Presiden Nomor 38 Tahun 2015, penyediaan infrastruktur bagi masyarakat meliputi infrastruktur ekonomi dan sosial. Ini meliputi infrastruktur transportasi, jalan, sumber daya air dan irigasi, air minum, sistem pengelolaan air limbah setempat, sistem pengelolaan persampahan, telekomunikasi dan informatika, konservasi energi, fasilitas perkotaan, fasilitas pendidikan, fasilitas sarana dan prasarana olahraga serta kesenian, fasilitas kesehatan, kawasan, pariwisata, lembaga permasyarakatan, dan perumahan rakyat. Bentuk-bentuk kerjasama yang diatur dalam kepres tersebut, meliputi:

1) Build and Transfer (BT), adalah suatu perjanjian di mana kedudukan kontraktor hanya membangun proyek tersebut, setelah selesai dibangunnya proyek tersebut maka proyek yang bersangkutan diserahkan kembali kepada pihak bowler tanpa hak kontraktor untuk mengelola/memungut hasil dari proyek tersebut. Dalam praktik build and transfer ini disebut dan dipadankan dengan contract design and build atau full finance sharing, turnkey project.

2) Build, Operate, Transfer (BOT), setelah membangun proyek tersebut pihak swasta kemudian berhak mengelola atau mengoperasikan proyek tersebut dalam waktu tertentu, dan dengan pengoperasian tersebut pihak swasta memperoleh keuntungan, dan setelah jangka waktu disepakati kemudian proyek tersebut diserahkan kepada pihak swasta tanpa memperoleh pembayaran dari pemerintah.

3) Kerjasama Bangun, Kelola, Sewa, dan Serah (Build, Operate, Leasehold, and Transfer, (BOLT)) adalah perjanjian antara pemerintah dengan pihak swasta dengan syarat, sebagai berikut: (a) pemerintah daerah memiliki aset (tanah); (b) pihak ketiga membangun di atas tanah milik pemerintah daerah; (c) pihak ketiga mengelola, mengoperasikan dengan menyewakan kepada pihak lain atau kepada pemerintah daerah itu sendiri; (d) pihak ketiga memberikan kontribusi dari hasil sewa kepada pemerintah daerah yang besarnya ditetapkan sesuai dengan kesepakatan; (e) jangka waktu kerjasama sesuai kesepakatan bersama; (f) setelah berakhirnya kerjasama pihak ketiga menyerahkan seluruh bangunan kepada pemerintah daerah.

4) Kerjasama Bangun, Serah, dan Kelola (Build, Transfer, and Operate (BO)) adalah perjanjian antara pemerintah dengan pihak swasta dengan syarat, sebagai berikut: (a) pemerintah daerah memiliki aset (tanah); (b) pihak ketiga membangun di atas tanah pemerintah daerah; (c) setelah pembangunan selesai pihak ketiga menyerahkan bangunan kepada pemerintah daerah; (d) pihak ketiga mengelola bangunan tersebut selama kerjasama; (e) pihak ketiga memberikan imbalan berupa uang atau bangunan lain kepada pemerintah daerah sesuai kesepakatan; (f) risiko selama masa kerjasama ditanggung oleh pihak ketiga; (g) setelah berakhirnya kerjasama, tanah dan bangunan tersebut diserahkan kembali kepada pemerintah daerah;

5) Kerjasama Rehabilitasi, Guna, dan Serah (Renovate, Operate, and Transfer 
(ROT)) memiliki syarat yang harus dipenuhi, sebagai berikut: pemerintah daerah memiliki aset (tanah dan bangunan); (b) pihak ketiga memiliki modal untuk merehabilitasi bangunan; (c) pihak ketiga mengelola bangunan selama kerjasama; (d) hasil pengelolaan seluruhnya menjadi hak pihak ketiga; (e) pihak ketiga tidak boleh mengagunkan bangunan; (f) jangka waktu kerjasama ditetapkan maksimal lima tahun; (g) setelah berakhirnya masa kerjasama, tanah dan bangunan diserahkan kepada pemerintah daerah dalam keadaan baik.

6) Kerjasama Renovasi, Guna Sewa, dan Serah (Renovate, Operate, Leasehold, and Transfer (ROLT)) adalah kerjasama antara pemerintah daerah dengan pihak ketiga dengan syarat- syarat sebagai berikut: (a) pemerintah daerah memiliki asset (tanah dan bangunan); (b) pihak ketiga merenovasi bangunan; (c) pihak ketiga mengelola dan mengoperasikan bangunan dan dengan menyewa dari pemerintah daerah untuk disewakan lagi pada pihak lain atau dipakai sendiri; (d) pihak ketiga memberikan kontribusi dari hasil sewa kepada pemerintah daerah yang besarnya ditetapkan sesuai kesepakatan; (e) pihak ketiga menanggung biaya pemeliharaan dan asuransi; (f) risiko kerjasama sesuai kesepakatan.

7) Kerjasama Bangun, Serah, dan Sewa (Build, Transfer, Leasehold (BTL)), adalah kerjasama antara pemerintah daerah dengan pihak ketiga dengan ketentuan: (a) pemerintah daerah memiliki aset (tanah); (b) pihak ketiga membangunkan di atas tanah pemerintah; (c) pihak ketiga menyerahkan bangunan kepada pemerintah daerah setelah selesai; (d) pihak ketiga mengelola, mengoperasikan bangunan dengan cara menyewakan pada orang lain; (e) pihak ketiga memberikan kontribusi kepada pemerintah daerah dari hasil sewa tersebut yang besarnya sesuai kesepakatan; (f) pihak ketiga menanggung biaya pemeliharaan; (g) risiko selama masa kerjasama ditanggung pihak ketiga.

\section{- Praktek Public Private Partnership di India}

Dalam artikel Barowalia (2010), berjudul "Public Private Partnership in Social Sectors for Harmonized Development in India", diuraikan bahwa negara federal India yang menganut paham welfare state, telah melakukan perbaikanperbaikan pelayanan publik sejak awal abad ke-21. Perbaikan pelayanan publik ini dilakukan dengan menerapkan konsep public private partnership, baik dalam bidang penyediaan pelayanan atau pembangunan fisik dan infrastruktur (jalan, jembatan, listrik, kereta api, dan lainnya), namun juga berkembang ke bidang pelayanan sektor sosial (sektor pendidikan, kesehatan, penyediaan air minum dan sanitasi, serta perlindungan lingkungan).

Dalam 12 tahun terakhir di India, model public private partnership telah membuktikan kesuksesannya. Meski demikian, terdapat beberapa isu yang muncul terkait dengan penerapan model tersebut, yakni (1) pengaturan batas-batas kewenangan dalam model tersebut; (2) competitive edge dari inisiatif yang dilakukan antara pihak pemerintah (public sector) dan pihak swasta (private sector); (3) dilema dalam hal permodalan; (4) kewajiban sosial dari pihak swasta: (5) nilai keadilan dan kesejahteran; dan (6) isu-isu kemanusiaan dan transformasi sosial. 
1. Model Public Private Partnership di Sektor Pendidikan

Di sektor pendidikan melalui model public private partnership mampu membuka akses pendidikan selebarlebarnya dan meningkatkan kualitas pendidikan yang dianggap masih menjadi kelemahan. Oleh pemerintah pusat mengalokasikan anggaran pendidikan tahun 2008-2009, ditingkatkan sebesar $20 \%$ dari tahun sebelumnya, bagi semua tingkatan pendidikan. Dengan partisipasi dari pihak swasta, maka pengeluaran total untuk pendidikan menjadi 5,3\%.

Model public private partnership memiliki kelebihan yang berbeda, sebagai sarana yang dapat membantu dalam mencapai hasil pendidikan yang diinginkan. Dari berbagai kasus di negara lain, dapat disimpulkan bahwa kelebihan dari penerapan model public private partnership dalam bidang pendidikan, pihak swasta selain berinvestasi modal, juga dapat memberikan fasilitasi bangunan dan manajemen organisasi pendidikan pada semua tingkatan. Termasuk juga manajemen sistem informasi yang dibutuhkan.

\section{Model Public Private Partnership di Sektor Kesehatan}

Penerapan konsep public private partnership, dianggap sangat tepat dan penting, karena tantangan sektor publik paling tampak di sektor kesehatan adalah keuangan, manajemen dan penyediaan fasilitas. Padahal peningkatan status kesehatan penduduk menjadi salah satu tujuan utama dari pembangunan sosial suatu negara.

Fokus penerapan public private partnership, di sektor kesehatan adalah pada pencegahan penyakit seperti infeksi menular seksual dan malaria, mengembangkan dan memfasilitasi akses terhadap vaksin dan obat-obatan, meningkatkan pelayanan kesehatan. Dalam konteks ini Indian harus membentuk "enabling task forces" badan pada setiap level (federal, negara bagian, dan lokal) untuk mengimplementasikan skema program dari public private partnership.

\section{Model Public Private Partnership di} Sektor Air Minum dan Sanitasi

Penyediaan pelayanan air bersih untuk minum dan sanitasi umumnya menjadi masalah di daerah pedesaan. Penyediaan air minum sangat terkait dengan kesehatan manusia dan kesejahteraan, terutama bagi ibu dan anak. Fasilitas sanitasi meningkatkan kesehatan dan kualitas hidup penduduk pendesaan. Umumnya, program penyediaan air minum dan sanitasi di India telah di anggarkan oleh pemerintah. Namum masih banyak yang belum terjangkau, sehingga pemerintah memberi kesempatan partisipasi bagi masyarakat dalam menciptakan dan memelihara air minum dan fasilitas sanitasi. Peran pemerintah hanya sebagai "provider" dan "facilitator". Alternatifnya melalui pengembangan konsep public-private-community partnership dalam mengatasi problema air minum dan sanitasi di pedesaan.

\section{Model Public Private Partnership Sektor Proteksi Lingkungan}

Jumlah penduduk India sekitar $16 \%$ dari totak populasi dunia. Sekitar $20 \%$ dari luas wilayah geografisnya menjadi lokasi peternakan. Kondisi tersebut membuat sistem lingkungan menjadi tertekan dan rawan. Akibatnya menjadi "soil erosion, water logging, salinity, nutrient depletion, lowering of the groundwater table and soil pollution". Penyebabnya karena intervensi dari besarnya populasi penduduk. Terjadi penebangan liar, perladangan berpindahpindah, eksploitasi melalui penebangan 
kayu bakar, dan kegiatan penambangan seharusnya menjadi keprihatinan seius.

Derajat kerusakan lingkungan yang digambarkan tersebut, menjadi salah satu perhatian serius pemerintah. Olehnya itu, pemerintah melakukan strategi kerjasama dalam bentuk kemitraan dengan pihak pengusaha terutama yang bergerak dibidang pengolahan hasil hutan. Juga mengundang masyarakat, terutama mereka yang hidupnya tergantung dari hasil hutan. Model public private community partnership, pada level lokal ini diterapkan, dengan mempromosikan konsep "green corporate practices".

\section{Model Public Private Partnership di Sektor Pemberdayaan Ibu dan Anak}

Masa depan India terletak pada masa depan anak-anak India. Mereka adalah aset tertinggi dan sumber daya manusia masa depan negeri. Semua stakeholders, seperti kelompok sukarelawan, asosiasi, federasi, serikat buruh, NGO, organisasi perempuan, serta institusi yang berhubungan dengan pendidikan, pelatihan, dan penelitian terlibat dalam pemantauan formulasi dan pelaksanaan, serta mengkaji semua kebijakan dan program yang berhubungan dengan pengembangan perempuan dan anak. Mereka diberikan dukungan dan diberi pula fasilitas untuk meningkatkan kapasitas dalam berpartisipasi aktif dalam proses pemberdayaan perempuan.

\section{Model Public Private Partnership di Sektor Pengembangan Agriculture}

Sektor swasta (perusahaan, LSM dan asosiasi industri, dan lainnya) bekerja sama dengan pihak pemerintah dalam rangka pembangunan pertanian di India. Sebagai asosiasi kunci utama seperti Bharat Chambers of Commerce, East India Cotton Association, The Federation of Andhra Pradesh Chambers of Commerce and Industry dan Indian Chambers of Commerce. Mereka ini melakukan kerja sama secara luas terkait dengan pengembangan bidang pertanian di India. Upaya dilakukan demi menuju produksi varitas tanaman yang unggul, melakukan proyek irigasi yang inovatif, produksi obatobatan, tanaman herbal dan aromatic, meningkatkan produksi kapas, mendorong pengembangan hutan sosial, budidaya ikan, dan pengembangan daerah kritis, dan lainnya.

Dapat dtegaskan bahwa penerapan konsep public private partnership, selain menjadi potensi yang cukup besar dalam pembangunan sektor sosial. Juga dapat memberi peluang bagi terbukanya berbagai jenis lapangan kerja bagi warga. Manfaat utamanya, program-program pembangunan sosial dan administrasi, legalitasnya dapat diisi oleh pihak pemerintah, sedangkan input pengetahuan dan teknologi, pemasaran dan dukungan keuangan berasal dari pihak swasta. Demikian halnya, di tingkat masyarakat lokal, dapat pula ditangani oleh baik pihak pemerintah maupun pihak swasta. Model ini menjadi tantangan dan juga peluang, tinggal bagaimana dikonversi menjadi situasi "win-win position” bagi semua.

\section{Isu dan Kendala Penerapan Public Private Partnership}

Isu dan hambatan yang terungkap dalam praktek model public private partnership, diuraikan seperti berikut ini:

a) Kemitraan antara sektor publik dengan sektor swasta munculnya masih baru. Akibatnya, sebagian besar sektor publik masih ragu (skepticcal) terhadap keuntungan konsep ini. Di sektor swasta pun muncul kekhawatiran tentang stabilitas politik dan ekonomi, transparansi hukum dan aturan. Terdapat juga beberapa kekurangan terhadap kapasitas dalam sektor publik, dalam menjalankan dan mengawasi kemitraan tersebut. Dibutuhkan institusi Copyright $@$ 2020, Publik (Jurnal Ilmu Administrasi), ISSN: 2301-573X (Print), ISSN: 2581-2084 (Online) 
yang memfasilitasi pelaksanaan public private partnership, seperti badan regulasi independen, juga tersedianya mekanisme penyelesaian sengketa yang belum ada.

b) Proyek-proyek infrastruktur mengalami isu-isu yang saling bertentangan, karena beberapa proyek dilaksanakan pada beberapa sektor dan lembaga (departemen) sebagai pelaksana. Misalnya, proyek pembangunan jalan biasanya melibatkan beberapa lembaga, seperti Departemen Pekerjaan Umum, Departemen Pendapatan, Departemen Kehutanan, dan lain-lain. Untuk itu, muncul isu kebijakan mengenai efektivias koordinasi antardepartemen dalam pengambilan keputusan secara cepat.

c) Praktek public private partnership mencakup keseluruhan proyek infrastruktur di semua sektor. Dalam proyek seperti listrik dan jalan secara konfrehensif kebijakan telah dikembangkan. Sementara di sektor seperti kereta api, air irigasi, dan saluran pembuangan masih sedikit telah dilakukan.

Selain isu-isu di atas, juga disebutkan bahwa sektor swasta dan sektor publik bekerja sama dalam bidang infrastruktur dan sektor sosial, keduanya tunduk dibawah otoritas regulasi dan pengawas yang ditunjuk. Pembiayaan infrastruktur dihadapi bersama. Mengingat adanya aspek eksternalitas, resiko yang tinggi dan tingkat pengembalian yang rendah, sisi pembiayaan tersebut tidak dapat hanya dibebankan pada sektor swasta. Demikian halnya, karena adanya keterbatasan anggaran dan inefisiensi yang melekat, pada sektor publik pun tak bisa selalu diandalkan.
Prinsip mendasar dari model public private partnership adalah sektor swasta bertanggung jawab atas pembiayaan desain bangunan dan pelaksanaan pelayanan. Sektor publik berada pada aspek legislasi dan penyediaan dukungan kelembagaan dan politik. Semua kesuksesan praktek model tersebut sangat dipengaruhi oleh komunikasi yang efektif dengan para stakeholders. Harus diingat bahwa meskipun sejak awal telah ada konsensus politik, perlu terus diperkuat. Akhirnya, landasan pada semua praktek model public private partnership adalah terletak pada kepercayaan dan saling menghormati.

Menurut hasil penelitian Paskarina (2007) yang dilakukan di Jawa Barat menunjukkan bahwa sebagai prediksi bila model public private partnership ini diterapkan, setidaknya terdapat tujuh kemungkinan pola interaksi kemitraan yang muncul, yaitu:

a) Seratus persen $(100 \%)$ pengaturan, kontrol dan evaluasi dilakukan pemerintah secara otonom dan mandiri.

b) Ada interaksi antara sektor publik dan sektor swasta. Interaksi ini terjadi pada derajat yang berbeda, bisa $99 \%$ publik dan $1 \%$ swasta atau sebaliknya $1 \%$ publik dan $99 \%$ swasta. Ada elemen-elemen yang contracting out (misalnya perawatan kendaraan, kebersihan) atau pembagian tugas (tindakan preventif dan pembangunan saluran hidran).

c) Dimungkinkan $100 \%$ peran sektor swasta, dengan tidak melibatkan masyarakat dan pemerintah, artinya penyediaan pelayanan sepenuhnya dikelola swasta, dengan tidak ada keterlibatan pemerintah baik pada regulasi maupun penyediaan fasilitas.

d) Ada interaksi antara pemerintah dan masyarakat. Pegawai fasilitas pelayanan, misalnya, merupakan 
kombinasi antara tenaga profesional pemerintah dan sukarelawan masyarakat.

e) Urusan pelayanan publik $100 \%$ menjadi urusan masyarakat. Tidak ada organisasi pemerintah maupun swasta yang telibat dalam perencanaan, pengadaan, dan penanganan masalah tersebut.

f) Kombinasi antara organisasi swasta yang berorientasi pada profit dengan LSM yang non-profit. Lembaga penyedia pelayanan mungkin ditangani swasta, tetapi dikombinasikan dengan tenaga profesional dan warga masyarakat.

g) Kombinasi dari tiga pilar governance: pemerintah (publik), swasta, dan masyarakat. Kombinasi tersebut sama dengan interaksi antara public dan private, tetapi dengan tambahan tenaga sukarelawan dari masyarakat (society).

\section{PENUTUP}

\section{Kesimpulan}

Model public private partnership secara konseptual sudah lama dikembangkan oleh berbagai ahli dan praktisi tata kelola pemerintahan. Dalam prakteknya di Indonesia dan India sudah merapkannya dalam berbagai bidang kehidupan masyarakat. Hal tersebut dilakukan untuk mengatasi kelemahan dalam hal manajemen, teknologi, dan juga keuangan. Dampaknya juga nyata karena dapat membuka lapangan pekerjaan yang baru bagi warga negara kedua negara tersebut. Disimpulkan pula bahwa di masa mendatang tidak hanya model public private partnership, yang perlu dikembangkan dalam penyediaan pelayanan publik.

\section{Saran}

Berdasarkan uraian Model public private and society (community) partnership juga perlu dikembangkan agar penyediaan pelayanan publik menjadi lebih dekat dan mudah diakses oleh masyarakat. Berbagai model jejaring kemitraan perlu dikembangkan tidak hanya untuk mengantisipasi tuntutan pelayanan publik, tetapi juga untuk mengantisipasi dominasi pemerintah atau pasar dalam penyediaan barang dan jasa publik.

\section{DAFTAR PUSTAKA}

Abdullah, Muhammad Tang. (2016). "Perspektif Governance Dalam Memahami Perubahan Manajemen Pemerintahan". Jurnal Analisis Kebijakan dan Pelayanan Publik (JAKPP). Volume 2 Nomor 1, hal. 65-71, Juni. pISSN: 2460-6162 eISSN: 2527-6476.

Akintoye, Akintola \& Matthias Beck. (2009). Policy, Finance \& Management for Public - Private Partnerships. United of Kingdom: Blackwell Publishing Ltd.

Barowalia, Aarushi. (2010). "Public Private Partnership in Social Sectors for Harmonized Development in India". OIDA International Journal of Sustainable Development. Volume I, hal. 29-37.

Bovaird, Tony. (2004). "Public-private partnerships: from contested concepts to prevalent practice". International Review of Admini-strative Sciences; 70; $199 . \quad$ DOI: $10.1177 / 0020852304044250$.

Kooiman, Jan. (1993). Modern Governance. London: Sage Publications

Kouwenhoven, Vincent. (1993). "The Rise of the Public Private Partnership". Dalam Jan Koolman. Modern Governance. London: Sage Publications. 
Link, Albert N. (2006). Public / Private Partnerships: Innovation Strategies and Policy Alternatives. New York: Springer.

Mahmudi. (2007). "Kemitraan Pemerintah Daerah dan Efektivitas Pelayanan Publik". Jurnal Sinergi: Kajian Bisnis dan Manajemen. Volume 9 Nomor 1, hal. 53-67, Januari. ISSN: $1410-9018$.

Mardiasmo. (2002). Akuntansi Sektor Publik, Yogyakarta: Penerbit Andi.

OECD. (1997). "Best Practice Guidelines for Contracting Out Government Services," PUMA Policy Brief Nomor 2.

Osborne, David \& Gaebler, Ted. (1992). Reinventing Government: How the Entrepreneurial Spirit is Transforming the Public Sector. New York: A William Patrick Book.

Paskarina, Caroline. (2007). Kemitraan Pemerintah dan Swasta dalam Pelayanan Publik. Laporan Utama, Warta Bapeda Provinsi Jawa Barat.

Savas, E.S. (1994). Privatization: The Key to Better Government. New York: Seven Bridges Press, LCC.

--------------. (2000). Privatization and Public-Private Partnership. New York: Seven Bridges Press, LCC.

Suryadi. 2010. “Analisis Motivasi Birokrasi dalam Pelayanan Publik". JIANA, Volume 10, Nomor 10, Juli. Fisip Universitas Riau, hal. 182-192.

Tarigan, Antonius. 2003. "Transformasi Model New Governance Sebagai Kunci Menuju Optimalisasi Pelayanan Publik di Indonesia". Bulletin USAHAWAN Nomor 02 Thn. XXXII Februari.

The Stationery Office. (2000). Public Private Partnership: The Government's Approach. London.
Utama, Dwinanta. (2010). “Prinsip dan Strategi Penerapan Public Private Partnership Dalam Penyediaan Infrastruktur Transportasi”. Jurnal Sains dan Teknologi Indonesia Volume 12, Nomor 3, Desember hal.145-151

Yaya, Riza. (2014). "Public-Private Partnerships: an International Development vis a vis Indonesia Experience". Journal of Govern-ment and Politics. Vol. 5 No. 2 August. Pp. 209-222.

Yescombe, E. R. (2007). Public-Private Partnerships, Principles of Policy and Finance. Oxford: Elsevier Ltd.

Zed, Mestika. (2004). Metode Penelitian Kepustakaan. Jakarta: YOI 